\title{
CHECK LIST OF SASKATCHEWAN MOTHS PART 12: DART MOTHS
}

RONALD R. HOOPER, Royal Saskatchewan Museum, 2340 Albert Street, Regina, Saskatchewan. S4P 3V7

Abbreviations used: $s=$ south; $n=$ north; $w=$ west e = east; $D A=D e-$ partment of Agriculture collection; $\mathrm{CNC}=$ the only known Saskatchewan records of the species that we know of are in the Canadian National Collection in Ottawa. (Unless otherwise indicated, all the species are represented in the collection of the Royal Saskatchewan Museum, formerly called the Saskatchewan Museum of Natural History.) The species are arranged according to the Check List of the Lepidoptera of North America (R.W. Hodges, 1983).

\section{Dart Moths (Noctuinae)}

These are Owlet Moths with naked eyes, spined middle and hind tibiae, and trifid venation on the hind wings (meaning that in this sub-family and some of the others that the mid-hind wing vein branches into three branches near the outer edge of the wing).

This is our largest sub-family of Owlet Moths. It contains many destructive cutworm moths that feed on a great variety of plants. Nearly all of the species are a drab brown in colour. An exception to this is the Catocaline Dart Moth, which has black-banded, yellow hind wings and is thus named after the underwing moths.
Part A - Agrotis, Onychagrotis, Feltia, Copablepharon and Euxoa

Old Man Dart - Agrotis vetusta Wlk. — s Sask., $\mathrm{n}$ to La Ronge.

Daedalus Dart -- Agrotis daedalus (Sm.) - Swift Current, Portreeve and Saskatoon.

Mollis Dart - Agrotis mollis WIk. n Sask., s to Shoal Lake, MacDowall, Richard and Cutknife.

Pale Western Cutworm - Agrotis orthogonia (Morr.) - s Sask., $\mathrm{n}$ to Aylsham.

King's Dart - Agrotis kingi McD. Saskatoon (CNC).

Robust Dart - Agrotis robustior (Sm.) - s Sask., n to Indian Head, Earl Grey, Saskatoon and Cochin.

Venerable Dart - Agrotis venerabilis Wlk. — s Sask., n to Red Earth.

Vancouver Dart - Agrotis vancouverensis Grt. - Piapot and Cypress Hills.

Musa Dart - Agrotis musa (Sm.) reported for Saskatchewan by J.D. LaFontaine. 


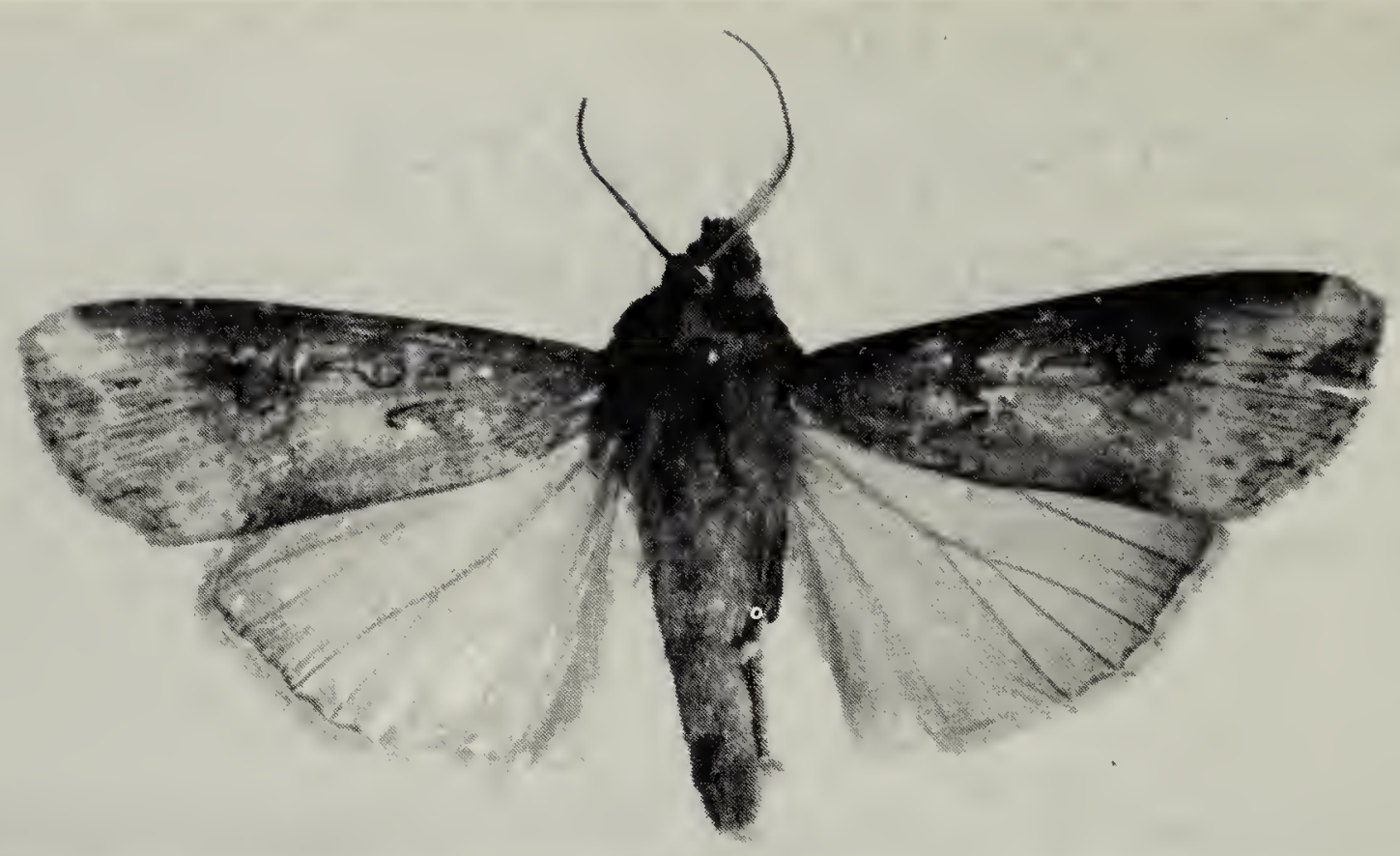

Dark Sword Grass (Agrotis ipsilon (Hufn.))

Keith Roney

Pointed Dart - Agrotis stigmosa Morr. - Swift Current, Cutknife and Harlan (ne of Lloydminster) (CNC).

Voluble Dart - Agrotis volubilis Harv. - s Sask., $n$ to Love and Ile-ala-Crosse.

Oblique Dart - Agrotis obligua (Sm.) - s Sask., $\mathrm{n}$ to Aylsham.

Dark Sword Grass - Agrotis ipsilon (Hufn.) - s Sask., $n$ to Aylsham.

Riley's Dart - Onychagrotis rileyana (Morr.) - Swift Current (DA, Saskatoon), Saskatoon (CNC).

Gothic Dart - Feltia jaculifera (Gn.) - $s$ Sask., $n$ to Aylsham and Snowden.

Hudson's Dart - Feltia hudsoni Sm. - Swift Current (CNC).

Dingy Cutworm - Feltia subgothica (Haw.) - Cypress Hills (West Block).

Master Dart - Feltia herilis (Grt.) s Sask., $\mathrm{n}$ to Aylsham.

The Grand Copablepharon - Copablepharon grande (Stkr.) - s Sask., $\mathrm{n}$ to Saskatoon.

The Gray Copablepharon - Copablepharon viridisparsum Dod. - sw Sask., e to Caron and Rockglen; $n$ to Waskesiu.

The Brown Copablepharon - Copablepharon longipenne Grt. - s Sask., $\mathrm{n}$ to Saskatoon and Rutland (nw of Unity).

Divergent Dart - Euxoa divergens (WIk.) - s Sask., $n$ to Cumberland House.

Reaper Dart - Euxoa messoria (Harr.) - s Sask., $\mathrm{n}$ to Aylsham.

Climbing Dart - Euxoa scandens (Riley) - s Sask., $\mathrm{n}$ to Aylsham and Loon Lake.

Golden Dart - Euxoa aurulenta (Sm.) - Aylsham, Saskatoon and Portreeve.

The Three-marked Dart - Euxoa tristicula (Morr.) - s Sask., $\mathrm{n}$ to Shoal Lake and Harlan (ne of Lloydminster).

Pleuritica Dart - Euxoa pleuritica (Grt.) - s Sask., $\mathrm{n}$ to Aylsham 


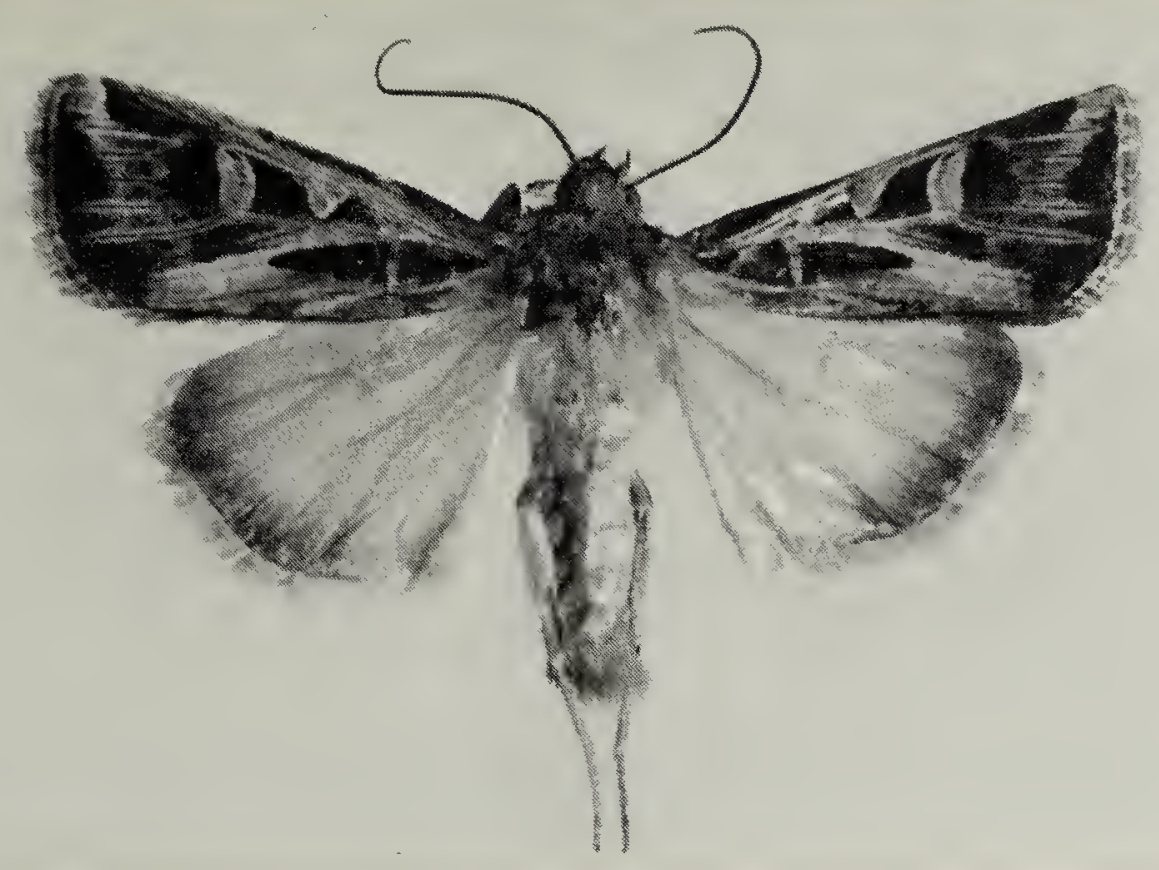

Gothic Dart (Feltia jaculifera (Gn.))

Keith Roney

(CNC) (DA, Saskatoon)

Pestula Dart - Euxoa pestula Sm. - s Sask., $n$ to Aylsham (CNC) (DA, Saskatoon).

Simon Dart - Euxoa simona McD. - reported for Saskatchewan by $\mathrm{H}$. McDonald.

Sordid Dart - Euxoa lidia thanatalogia (Dyar) - s Sask., $n$ to Aylsham.

Army Cutworm - Euxoa auxiliaris (Grt.) - s Sask., $\mathrm{n}$ to Aylsham and Prince Albert.

Ruddy Dart - Euxoa mimallonis (Grt.) - s Sask., $\mathrm{n}$ to Norquay and Prince Albert.

Olivia Dart - Euxoa olivia (Morr.) s Sask., $n$ to Aylsham.

Tippling Dart - Euxoa intrita (Morr.) - Maryfield, Shoal Lake, Aylsham and Saskatoon.

Clear Dart - Euxoa declarata (WIk.) - s Sask., $n$ to Aylsham and Battlefords Provincial Park.

Flat Dart - Euxoa campestris (Grt.) - s Sask., $n$ to La Ronge.
Foamy Dart - Euxoa spumata McD. - reported by J.D. LaFontaine for the Swift Current area and the Moose Jaw area.

The Pale Dart - Euxoa pallipennis (Sm.) - Buffalo Pound Provincial Park, Coronach and Swift Current.

Misturata Dart - Euxoa misturata (Sm.) - reported for sw Sask. by J. D. LaFontaine (Maple Creek and Val Marie areas).

The Utah Dart - Euxoa cinereopallida (Sm.) - Eastend (CNC).

Spineless Dart - Euxoa mitis (Sm.) - Eastend and Swift Current (CNC).

Acornis Dart - Euxoa aequalis acornis (Sm.) - s Sask., $\mathrm{n}$ to Punnichy and Duck Lake.

Hairy Dart - Euxoa comosa (Morr.) - s Sask., $n$ to Fort Esperance (e of Tantallon), Punnichy and Saskatoon.

Variable Dart - Euxoa infausta (Wlk.) - Oxbow.

Pale-based Dart - Euxoa basalis (Grt.) - s Sask., $\mathrm{n}$ to Aylsham. 
The Grand Copablepharon (Copablepharon grande (Stkr.))

Keith Roney

Red Backed Cutworm - Euxoa ochrogaster (Gn.) — s Sask., $\mathrm{n}$ to Aylsham and MacDowall.

Plaited Dart - Euxoa plagigera (Morr.) - s Sask., $\mathrm{n}$ to Aylsham.

Tesselate Dart - Euxoa tessellata (Harr.) - throughout Sask.

White-winged Dart - Euxoa albipennis (Grt.) — s Sask., $\mathrm{n}$ to Aylsham and Duck Lake.

Chain-dotted Dart - Euxoa catenula (Grt.) - s Sask., $n$ to Fort Qu'Appelle and Buffalo Pound Provincial Park.

Median-banded Dart - Euxoa medialis (Sm.) - Swift Current (CNC).

Elegant Dart - Euxoa perexcellens (Grt.) - Melfort (DA, Saskatoon).

Obelisk Dart - Euxoa obeliscoides (Gn.) - s Sask., $n$ to Fort Qu'Appelle and Saskatoon.

Oberfoell's Dart - Euxoa oberfoelli Hdwk. - Scout Lake (CNC).

Choris Dart - Euxoa choris (Harv.)

- DA, Saskatoon.
White-underwing Dart - Euxoa brevipennis (Sm.) - Saskatoon (National Research Council collection), Swift Current (DA).

Chestnut Brown Dart - Euxoa castanea (LaFontaine) - s Sask., $\mathrm{n}$ to Aylsham.

Idaho Dart - Euxoa idahoensis (Grt.) - sw Sask., n to Saskatoon, e to Fort Qu'Appelle.

Closed Dart - Euxoa clausa McD. - Swift Current and Willow Bunch areas (reported by J. D. LaFontaine).

Lactificans Dart - Euxoa lactificans (Sm.) - Elbow area, Cypress Hills area and Shaunavon area (reported by J. D. LaFontaine).

Four-toothed Dart - Euxoa quadridentata (G. \& R.) - s Sask., $n$ to Red Earth and Prince Albert area.

White-lined Dart - Euxoa niveilinea (Grt.) - Regina and Gull Lake (reported by J. D. LaFontaine).

Olivalis Dart - Euxoa olivalis (Grt.) - Killdeer and Val Marie.

Oblong Dart - Euxoa oblongistigma 


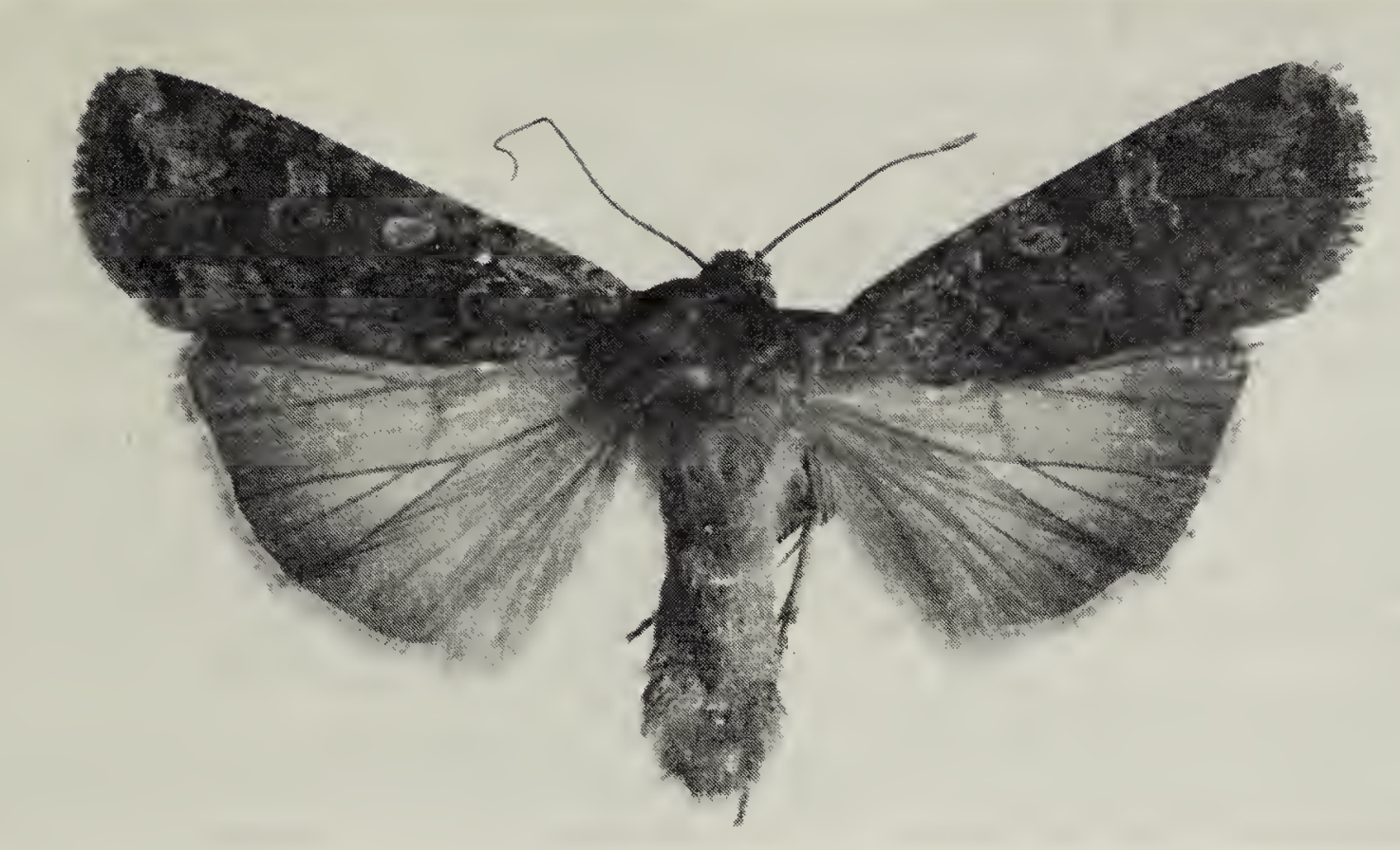

Army Cutworm (Euxoa auxiliaris (Grt.))

Keith Roney

(Sm.) - sw Sask., $\mathrm{n}$ to Swift Current area and e. to Val Marie area (reported by J. D. LaFontaine).

Dargo Dart - Euxoa dargo (Stkr.) s Sask., $n$ to Aylsham and North Battleford area (CNC).

Saskatoon Dart - Euxoa unica McD. - Saskatoon (CNC).

Rubbed Dart - Euxoa detersa (WIk.) - s Sask., $\mathrm{n}$ to La Ronge.

Scared Dart - Euxoa cicatricosa (G. \& R.) $-s$ Sask. $n$ to Aylsham (CNC).

Tronella Dart - Euxoa tronella (Sm.)

- Buffalo Pound Provincial

Park, Swift Current area and Shaunavon area.

Teleboa Dart - Euxoa teleboa (Sm.) - $\mathrm{s}$ Sask., $\mathrm{n}$ to Indian Head area and Saskatoon area (reported by J. D. LaFontaine).

Difformis Dart - Euxoa difformis (Sm.) - Saskatoon (National Research Council collection).

Mourning Dart - Euxoa moerens (Grt.) - Fort Qu'Appelle, Sask. Landing Provincial Park and Shaunavon area.

Dod's Dart - Euxoa dodi McD. - s

Sask., $\mathrm{n}$ to Buffalo Pound Provincial Park area and Lancer area (reported by J. D. LaFontaine).

Broken Dart - Euxoa infracta (Morr.) - Killdeer area (reported by J. D. LaFontaine).

Fillet Dart - Euxoa redimicula (Morr.) - Aylsham and Cypress Hills (CNC).

Auripennis Dart - Euxoa auripennis LaFontaine - s Sask., $n$ to Nipawin area.

Servita Dart - Euxoa servita (Sm.) - s Sask., $\mathrm{n}$ to Somme and Waskesiu area.

Munis Dart - Euxoa munis (Grt.) Canora, Lestock, Punnichy, Quinton and Fort Qu'Appelle.

Regina Dart - Euxoa taura Sm. (= E. cooki) - Regina (Type Locality), Swift Current and Killdeer.

Perolivalis Dart - Euxoa perolivalis (Sm.) - s Sask., $\mathrm{n}$ to Aylsham.

Ridings' Dart - Euxoa ridingsiana (Grt.) - s Sask., $\mathrm{n}$ to Aylsham.

Maimes Dart - Euxoa maimes (Sm.) - s Sask., $\mathrm{n}$ to Wadena and Tramping Lake Regional Park.

Manitoba Dart - Euxoa manitobana 
McD. - s Sask., $\mathrm{n}$ to Saskatoon.

Yellow-lined Dart - Euxoa flavicollis (Sm.) - s Sask., $\mathrm{n}$ to Aylsham and Duck Lake.

Unmarked Ruddy Dart - Euxoa perpolita (Morr.) - s Sask., $\mathrm{n}$ to Aylsham.

\section{Expected Species}

Tricosa Dart - Feltia tricosa (Lint.) - $w$ to Brandon, Manitoba (CNC).

Quebec Dart - Euxoas quebecensis (Sm.) - across Canada, but missed in Manitoba and Saskatchewan.

Cona Dart - Euxoa cona (Stkr.) $\mathrm{n}$ to Malta, Montana and $\mathrm{w}$ North Dakota.

Nostra Dart - Euxoa nostra (Sm.) - $n$ to $s$ British Columbia and $s$ Alberta, with a disjunct population at Fort Smith, N.W.T.

Fleece-winged Dart - Euxoa velleripennis (Grt.) - w to Cartwright, Manitoba and se Montana.

Holleman's Dart - Euxoa hollemani (Grt.) (= E. andera) - Arizona, $\mathrm{n}$ to British Columbia and Malta, Montana.

Lemon-coloured Dart - Euxoa citricolor (Grt.) - $\mathrm{n}$ to Badlands of North Dakota and Alberta.

Wandering Dart - Euxoa aberrans (McD.) - s British Columbia and $s$ Alberta, $e$ to $s$ Manitoba and Michigan, but missed so far in Saskatchewan.

\section{References}

BYERS, J.R., D.L. STRUBLE, and J.D. LAFONTAINE. 1966. Biosystematics of the genus Euxoa (Lepidoptera: Noctuidae) XVIII. Comparative biology and experimental taxonomy of the sibling species Euxoa ridingsiana (Grt.) and
Euxoa maimes (Sm.). Can. Ent. 117: 481-493.

HARDWICK, D.F. 1970. The genus Euxoa (Lepidoptera:Noctuidae) in North America 1. Subgenera Orsagrotis, Longivesica, Chorizagrotis, Pleonectopoda and Grassivessica. Mem. Ent. Soc. Can. 67:1-177, figs. 1-326.

HODGES, R.W. (editor). 1983. Check list of the Lepidoptera of America North of Mexico. E.W. Classey, and the Wedge Entomological Research Foundation, London, England. 284 pp.

LAFONTAINE, J.D. 1974. The punctigera group of the genus Euxoa (Lepidoptera: Noctuidae), with descriptions of two new species. Can. Ent. 106:1233-1240.

1975. The misturata group of the genus Euxoa (Lepidoptera:Noctuidae), with a description of a new species. Can. Ent. 107-1327-1332.

1976a. A synopsis of the aequalis group of the genus Euxoa Hbn. (Lepidoptera: Noctuidae) with a description of a new species from southwestern United States. Can. Ent. 108: 741-750.

1976b. A new species of Euxoa (Lepidoptera: Noctuidae) allied to Euxoa olivia and Euxoa septentrionalis. Can. Ent. 108:1275-1280.

— 1987. The moths of America North of Mexico, Fascicle 27.2, Noctuoidea, Noctuidae (Part), Noctuinae (PartEuxoa). The Wedge Entomological Research Foundation, Washington, D.C. $237 \mathrm{pp}$.

LAFONTAINE, J.D., and J.R. BYERS. 1982. A revision of the comosa group of the genus Euxoa Hbn. (Lepidoptera: Noctuidae), with descriptions of two new species. Can. Ent. 114:575-589.

MCDUNNOUGH, J. 1932. Notes on Agrotid genera with description of a new species. Can. Ent. 64:104-112.

1932. Notes on the synonymy of certain Euxoa species with descriptions of new species. Can. Ent. 64:229-236. 